\title{
Effects of Temperature on Physiology and Reproductive Success of a Montane Leaf Beetle: Implications for Persistence of Native Populations Enduring Climate Change
}

\author{
Elizabeth P. Dahlhoff ${ }^{1,2, *}$ \\ Shannon L. Fearnley ${ }^{2,3}$ \\ Douglas A. Bruce ${ }^{2,3}$ \\ Allen G. Gibbs ${ }^{4}$ \\ Robin Stoneking ${ }^{2,3}$ \\ David M. McMillan ${ }^{1,2, \dagger}$ \\ Kristy Deiner ${ }^{2,3, *}$ \\ John T. Smiley ${ }^{2}$ \\ Nathan E. Rank ${ }^{2,3}$ \\ ${ }^{1}$ Department of Biology, Santa Clara University, Santa Clara, \\ California 95053; ${ }^{2}$ University of California, White Mountain \\ Research Station, Bishop, California 93514; ${ }^{3}$ Department of \\ Biology, Sonoma State University, Rohnert Park, California \\ 94928; ${ }^{4}$ School of Life Sciences, University of Nevada, Las \\ Vegas 89154
}

Accepted 5/16/2008; Electronically Published 10/28/2008

Online enhancement: appendix.

\begin{abstract}
Understanding how climate change impacts natural systems requires investigations of the effects of environmental variation on vulnerable species and documentation of how populations respond to change. The willow beetle Chrysomela aeneicollis is ideal for such studies. It lives in California's Sierra Nevada on the southern edge of its worldwide range. Beetles experience elevated air temperatures during summertime egg laying and larval development. Exposure to these temperatures causes physiological stress, which may reduce reproductive success and endanger populations. The glycolytic enzyme phosphoglucose isomerase (PGI) is a marker of temperature adaptation in $C$. aeneicollis. PGI allele frequency varies across a latitudinal gradient: allele 1 is common in Rock Creek (RC), which is cooler and to the north, and allele 4 is common in Big Pine Creek

\footnotetext{
*Corresponding author; e-mail: edahlhoff@scu.edu.

${ }^{\dagger}$ Present address: Organismic and Evolutionary Biology, University of Massachusetts, Amherst, Massachusetts 01003.

${ }^{\ddagger}$ Present address: Department of Animal Science, University of California, Davis, California 95616.
}

Physiological and Biochemical Zoology 81(6):718-732. 2008. (C) 2008 by The University of Chicago. All rights reserved. 1522-2152/2008/8106-8109\$15.00 DOI: $10.1086 / 590165$
(BPC), which is warmer and to the south. In populations that are intermediate in geography and climate (e.g., Bishop Creek $[\mathrm{BC}])$, PGI-4 frequency increases from north to south such that alleles 1 and 4 are in relatively equal frequency in southern BC. Over the past decade, Sierra Nevada beetle populations have colonized high elevations and have become extinct at lower elevations where they were once common. In BC, the magnitude of PGI allele frequency fluctuations among lifehistory stages is related to maximal air temperature, with the frequency of PGI-4 increasing after the hottest part of summer. To identify mechanisms that may cause shifts in PGI allele frequency, we measured metabolic rate and fecundity for beetles collected at BC. Metabolic rate of males and females was measured at $20^{\circ}$ and $36^{\circ} \mathrm{C}$ using flow-through respirometry. To measure laboratory fecundity, mating pairs were acclimated for $4 \mathrm{~h}$ each afternoon at a control temperature $\left(20^{\circ} \mathrm{C}\right)$ or at mildly elevated temperatures $\left(26^{\circ}\right.$ or $\left.32^{\circ} \mathrm{C}\right)$ and number of eggs laid was counted daily for $24 \mathrm{~d}$, after which tissue levels of $70-\mathrm{kD}$ heat shock proteins (Hsp70) were determined. Previous studies had demonstrated differences in Hsp70 expression among PGI genotypes at these temperatures. To measure field fecundity, mating pairs from $\mathrm{BC}$ were transplanted to similar elevations in BPC, BC, and RC and were monitored in situ for $24 \mathrm{~d}$. Metabolic rate was higher for PGI 4-4 genotypes than for PGI 1-4 or PGI $1-1$ individuals at $36^{\circ} \mathrm{C}$ but not at $20^{\circ} \mathrm{C}$. In contrast, laboratory fecundity was greatest for females possessing PGI1 , independent of acclimation temperature. At the end of the laboratory fecundity experiment, Hsp70 expression was positively related to fecundity, suggesting minimal reproductive cost of upregulation of heat shock proteins in response to mild heat stress. In the field, fecundity was highest for PGI 1-1 and PGI 1-4 individuals in RC and PGI 4-4 individuals in BPC and was similar for all genotypes in BC. Thus, fecundity in nature was greatest for the genotypes that were most common in each area. Taken together, data reported here suggest that hot, dry summers in the Sierra Nevada may result in an increase in frequency of the PGI-4 allele and shifts to higher elevations for C. aeneicollis populations.

\section{Introduction}

One of the many challenges posed by global climate change is that natural populations will respond unpredictably to an increasingly variable climate. In recent years, ranges of many 
species have shifted, with local extinction in some areas and colonization of new regions (Sagarin et al. 1999; Inouye et al. 2000; Hill et al. 2002; McLaughlin et al. 2002; Parmesan and Yohe 2003; Parmesan 2006). On the other hand, some species have shown no evident range shift or change in population size (Parmesan et al. 1999; Erasmus et al. 2002), whereas others have precipitously declined in both range and abundance (McLaughlin et al. 2002). Predicting which populations will be vulnerable to extinction is complicated by the fact that small changes in climate lead to large, unpredictable changes in air temperature, rainfall, and persistence of snow (Miller et al. 2003; Pearson and Dawson 2003; Hayhoe et al. 2004; Crozier and Dwyer 2006; Whitham et al. 2006). The ability of a population to persist in the face of environmental change will depend on the effects of abiotic stress on individual survival, physiological performance, and reproductive output (Karlsson and Wiklund 2005; Chamaille-Jammes et al. 2006; Lester et al. 2007; Musolin 2007; Reed et al. 2007), phenotypic plasticity (Garland and Kelly 2006; Ghalambor et al. 2007; Nussey et al. 2007), interactions with other species (Leonard 2000; Bertness and Ewanchuk 2002; Petes et al. 2007; Brooker et al. 2008), and the population's genetic composition (Haag et al. 2005; Hanski and Saccheri 2006). Although effects of climate change on natural populations have been extensively investigated, researchers have only recently begun to identify specific features that might allow populations to persist in a changing environment (Helmuth et al. 2002; McLaughlin et al. 2002; Pearson and Dawson 2003; Bradshaw et al. 2004; Ellis and Post 2004; Balanya et al. 2006; Bradshaw and Holzapfel 2006; Gilman et al. 2006; Harley et al. 2006; Svensson et al. 2006; Umina et al. 2006; Tran et al. 2007).

Fluctuations in environmental temperature may become more extreme as a result of climate change (Easterling et al. 2000; Diffenbaugh et al. 2005). This will be especially problematic for small, free-living ectotherms, because their body temperature is determined by the environment (Stevenson 1985). Large variations in body temperature may be metabolically costly because of an activation of cellular repair mechanisms after exposure to stress (Hofmann and Somero 1995; Feder and Hofmann 1999; Anestis et al. 2007; Li et al. 2007). Activation of heat shock proteins (Hsps) and other repair mechanisms may elevate metabolic rate due to increased demand for ATP at higher temperatures, or it may cause metabolic suppression due to shunting of ATP away from biosynthetic and activity pathways (Hoffmann and Rinas 2001; Sorensen et al. 2003; Lesser and Kruse 2004). This may ultimately lead to reduced performance and reproductive success (Krebs and Feder 1997; Loeschcke et al. 1997; Krebs and Holbrook 2001; Sorensen and Loeschcke 2002). Many ectotherms live close to the edge of their physiological tolerance in nature (Feder et al. 2000; Sorensen et al. 2003; Angilletta et al. 2006). Thus, small changes in climate may lead to rapid changes in abundance, in part due to effects of physiological stress. Earlier studies have demonstrated effects of temperature variation on physiology, survival, and reproductive success of small ectotherms (Boggs and
Freeman 2005; Hodkinson 2005; Karlsson and Wiklund 2005; McMillan et al. 2005; Dillon et al. 2007; Rank et al. 2007). A next critical step is to investigate impacts of abiotic stress on features that are critical for population persistence in a natural setting where effects of climate change are rigorously documented.

Montane regions are ideal systems in which to study mechanisms by which organisms cope with a changing environment (Franklin and MacMahon 2000; Hampe and Petit 2005). In mountains, populations experience different environmental conditions over small spatial scales, resulting in distinct climatic regimes within the typical dispersal range of many organisms. Montane organisms may be especially vulnerable to climate change (Hill et al. 2002; Peterson 2003; Hodkinson 2005; Gworek et al. 2007) because warmer temperatures may result in both increased exposure to extreme cold in early spring due to loss of protective snow cover and increased exposure to hotter, drier summers (IPCC 2007). Here we describe studies of a model organism for investigating climate change in montane habitats, the willow beetle Chrysomela aeneicollis, which lives at a high elevation $(2,700-3,600 \mathrm{~m})$ in the Eastern Sierra Nevada. Adults emerge from diapause in May or June to feed, mate, and lay eggs. Near the end of July, larvae pupate, and, shortly thereafter, new adults emerge (Smiley and Rank 1986; Rank 1994). Sierra Nevada populations of C. aeneicollis are found at the southern edge of this beetle's worldwide range and probably endure greater extremes in environmental temperature during summertime egg laying and larval development than do conspecifics living at higher latitudes (Rank and Dahlhoff 2002; Dahlhoff and Rank 2007).

In these populations, we have documented differences in expression levels of 70-kD Hsps (Hsp70), a key indicator of physiological stress in nature (Feder and Krebs 1997; Sorensen et al. 2003; Dahlhoff 2004; Dahlhoff and Rank 2007). The expression levels of Hsp70 vary among drainage areas (Big Pine Creek [BPC] > Bishop Creek [BC] > Rock Creek [RC]), and, within a drainage area, Hsp70 levels decline with increasing elevation. Expression levels of $\mathrm{Hsp} 70$ vary considerably throughout the day, reaching the highest levels in midafternoon, when beetle body temperatures routinely exceed $30^{\circ} \mathrm{C}$ (Dahlhoff and Rank 2000; Rank and Dahlhoff 2002). Cold stress may also be a constraint for $C$. aeneicollis in montane habitats. Nighttime temperatures may fall below $-8^{\circ} \mathrm{C}$ in June and July; we have observed mortality of $C$. aeneicollis after these subzero nighttime temperatures on multiple occasions (Smiley and Rank 1986; Rank 1994; McMillan et al. 2005). Upregulation of Hsps during the day may protect an individual exposed to freezing conditions at night (Rank and Dahlhoff 2002; Neargarder et al. 2003).

A unique aspect of Sierra Nevada beetle populations is the presence of a genetic polymorphism that shows evidence of being acted on by temperature selection. The genetic marker for this polymorphism is the allozyme phosphoglucose isomerase (PGI), which is an enzyme that is critical for energy metabolism and which shows evidence of being under tem- 
perature selection in diverse ectotherms (Watt 1992; Riddoch 1993; Reznick and Travis 1996). In Sierra Nevada beetle populations, PGI shows much greater differentiation among drainage areas than any other polymorphic enzyme locus (Rank 1992; Dahlhoff and Rank 2000). Allele 1 predominates in populations living in the northern drainage, $\mathrm{RC}$, whereas allele 4 predominates in the southern drainage, BPC. Allele frequencies are intermediate in the middle drainage, BC. This allele frequency gradient at PGI occurs along a temperature gradient. Typically, RC is the coolest, BPC is the warmest, and BC temperatures are intermediate (Rank and Dahlhoff 2002; Dahlhoff and Rank 2007).

Our earlier work suggests that variation at the PGI locus is consistently related to traits that allow individuals to cope with elevated and subzero temperatures in nature. Individuals with allozymes of PGI differ in thermal stability (PGI 4-4 > PGI 1-4 > PGI 1-1) and $K_{\mathrm{m}}$ of fructose-6P, which is a measure of enzyme binding effectiveness (Dahlhoff and Rank 2000). In addition, catalytic efficiency (indexed by maximum velocity over $\left.K_{\mathrm{m}}\left[V_{\max } / K_{\mathrm{m}}\right]\right)$ for individuals with the PGI 4-4 allozyme is lower (less efficient) at $10^{\circ}$ and $20^{\circ} \mathrm{C}$ than for those with the PGI 1-1 allozyme but is higher (more efficient) at higher temperatures $\left(30^{\circ}-40^{\circ} \mathrm{C}\right.$; E. P. Dahlhoff, unpublished data). Peak Hsp70 induction temperature after exposure to elevated temperatures is lower for individuals possessing the less stable form of the enzyme (PGI 1-1; maximal Hsp70 expression at $30^{\circ} \mathrm{C}$ ) than for those with the more stable form PGI 4-4 (maximal Hsp70 expression at $36^{\circ} \mathrm{C}$; Rank and Dahlhoff 2002). In addition, after a single heat or cold shock, individuals with PGI 1-1 genotypes are more thermotolerant and run faster than PGI 4-4 individuals; PGI 1-4 heterozygotes are typically intermediate (Neargarder et al. 2003; Rank et al. 2007). However, repeated exposure over consecutive days to extreme heat or cold reverses these patterns (PGI 4-4 > PGI 1-4 > PGI 1-1). These data suggest that PGI allele 4 is associated with greater tolerance of repeated thermal stress than allele 1 but that allele 1 is associated with better performance and a more vigorous heat shock response after exposure to a single elevated (or subzero) temperature (Dahlhoff and Rank 2007; Rank et al. 2007).

We have not yet identified the mechanisms that cause the observed relationship between PGI genotype and Hsp70 expression level in $C$. aeneicollis. One possibility is that Hsp70 molecules interact directly with PGI molecules (e.g., Hsp70 may respond to PGI allozymes that partially unfold at different temperatures). Another possibility is that PGI interacts with factors that regulate expression of Hsp70. Presence of PGI may also affect Hsp expression levels indirectly. For example, if PGI allozymes regulate flow of glucose through glycolysis differently (Zamer and Hoffmann 1989; Eanes 1999), this may result in differences among genotypes in ATP production. This could in turn affect the enzymatic activity of Hsps, which require ATP to catalyze protein refolding. Another possibility is that PGI is in linkage disequilibrium with Hsp70 itself or with genes that regulate $\mathrm{Hsp} 70$ expression. In any case, functionally important genetic variation affects the heat shock response and may allow populations to respond adaptively to environmental change.

In this study we document changes in distribution, abundance, and genetic composition of Eastern Sierra Nevada populations of $C$. aeneicollis in response to climate change, using PGI as a marker of temperature adaptation. In addition, we examine effects of environmental temperature variation on metabolic rate and fecundity, two features of individual performance that may influence population persistence. We also explore the relationship between fecundity and Hsp70 levels after exposure to mild, chronic heat stress typical of conditions in nature, and we ascertain whether differences in Hsp70 expression among PGI genotypes affect fecundity.

\section{Material and Methods}

\section{Population Genetics}

To examine structure of Eastern Sierra Nevada populations of Chrysomela aeneicollis, adults were collected in July 1997 from three drainages (BPC, BC, and RC). Genotype frequency data for BPC and RC populations were published previously and are included here for comparison (Dahlhoff and Rank 2000). Six subdrainages within BC were surveyed across a similar elevation gradient, and mean allele frequency of each subdrainage was calculated. BC subdrainage localities, sample sizes, and sampling elevation ranges are shown in Table 1.

To quantify changes in allele frequency over a single summer within BC subdrainages, beetles were collected from seven populations in the south fork of BC from the Green Lake (GL) and Chocolate Lakes (CL) subdrainages, where PGI alleles 1 and 4 are both common. A total of 35 beetles were collected from each site three times during the summer of 2001: overwintered adults (which had just emerged from winter diapause; June 7-8), third-instar larvae (August 6-7), and newly emerged adults (September 8-9). After collection, beetles were flash frozen and stored at $-80^{\circ} \mathrm{C}$ until genotype analysis was performed.

To measure variation in the local climate within BC, micro-

Table 1: Population genetics sample sizes and sampling localities

\begin{tabular}{lccl}
\hline Basin, Subdrainage & Sites & $n$ & $\begin{array}{l}\text { Elevation } \\
\text { Range }(\mathrm{m})\end{array}$ \\
\hline Rock Creek $^{\mathrm{a}}$ & 3 & 153 & $2,705-3,317$ \\
North Bishop Creek: & & & \\
$\quad$ Paiute Pass & 9 & 166 & $2,564-3,276$ \\
$\quad$ Blue Lake & 3 & 48 & $3,127-3,164$ \\
$\quad$ Lake Sabrina & 7 & 138 & $2,875-3,274$ \\
South Bishop Creek: & & & \\
$\quad$ Tyee Lakes & 2 & 66 & $3,134-3,227$ \\
$\quad$ Green Lake & 10 & 288 & $2,760-3,286$ \\
$\quad$ Chocolate Lakes & 10 & 192 & $2,983-3,230$ \\
Big Pine Creek & 3 & 60 & $2,960-3,332$ \\
\hline a & $3 a t a$ are from Dahlhoff and Rank (2000) &
\end{tabular}

${ }^{a}$ Data are from Dahlhoff and Rank (2000). 
habitat air temperature at each site was measured every $30 \mathrm{~min}$ throughout the summer using TidbiT temperature data loggers (Onset Computer, Pocaset, MA). Loggers were suspended in white plastic cups and secured onto host willow branches 1.5 $\mathrm{m}$ above the ground. Our earlier studies demonstrated that this arrangement gave us an excellent measure of the relationship between $T_{\mathrm{a}}$ and beetle $T_{\mathrm{b}}$ (Dahlhoff and Rank 2000); the white cup functions as a shield from direct solar radiation in summer (preventing overestimates of $T_{\mathrm{a}}$ ) and protects the logger housing from damage when loggers are buried in snow each winter. Daily mean maximum, mean minimum, and mean average temperature values were determined for each site from logger data using Boxcar Pro (ver. 4.0, Onset Computer).

\section{Abundance}

Adult beetle population abundance was quantified in 1998, 2003, and 2007 for seven to 12 sites in each of the three main study drainages along replicate elevation transects that were 8$12 \mathrm{~km}$ in length (elevation, 2,700-3,600 m). First surveys were initiated at snowmelt or in late May, whichever came first. Beetles were never observed before late May, even in years of early snowmelt. Surveys were repeated every 6-10 d throughout June and early July, as long as adult beetles were present. To perform a survey, two observers hiked to each locality, identifying the exact site using a handheld GPS unit (Geo Explorer, Trimble Corporation, Sunnyvale, CA). Abundance was determined by timed visual survey of approximately $25-100 \mathrm{~m}^{2}$ of willow bog, stream, or meadow for 10 person-minutes. Each observer selected a location near willow plants and closely scanned for beetles in the foliage while moving throughout suitable microhabitats. Number of beetles was recorded using a handheld cell counter. Raw data were converted to scaled counts $(0$, none; $1,1-3 ; 2,4-10 ; 3,11-40 ; 4,41-99 ; 5,100$ $300 ; 6,>300)$. Data reported are abundances observed the week of peak abundance each year, averaged over all three drainages.

\section{Effects of Temperature on Metabolic Rate}

Metabolic rate was measured for overwintered adults that were collected in June 2005 at sites at an altitude of 3,100-3,200 m in the CL and GL subdrainages in BC (Bluff Lake, South Lake Pipeline, Mary Louise Creek, and Bull Lake). After collection, sexes were separated to minimize effects of mating activity on metabolic rate and maintained in controlled-temperature incubators at natural diurnal light cycles $\left(14 \mathrm{~L}: 10 \mathrm{D} ; 20^{\circ} \mathrm{C}\right.$ day, $4^{\circ} \mathrm{C}$ night) at White Mountain Research Station (WMRS) in Bishop, California, for $7 \mathrm{~d}$. Beetles were fed fresh leaves from their favored host plant Salix orestera and given moisture via a piece of dampened filter paper placed in a petri dish. After laboratory acclimation, beetles were transported (in a $4^{\circ} \mathrm{C}$ cooler) from WMRS to the University of Nevada, Las Vegas, for metabolic rate measurements. Beetles were deprived of food for 4-6 d before measurements were taken. Individuals were randomly assigned to one of two measurement temperatures $\left(20^{\circ}\right.$ or $\left.36^{\circ} \mathrm{C}\right)$ and weighed immediately before determination of metabolic rate.

Metabolic rate (indexed by carbon dioxide production) and water loss rates were measured using flow-through respirometry. Beetles were placed in 5-mL glass-aluminum respirometry chambers and dry, carbon dioxide-free air was pumped

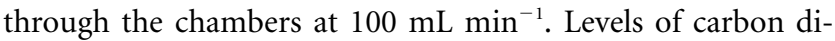
oxide and water vapor in the air stream were measured with a Licor LI-6262 infrared gas analyzer (LI-COR Biosciences, Lincoln, NE). Beetle activity was monitored during respirometry using AD-1 activity detectors (Sable Systems, Las Vegas, NV). These use a near-infrared photocell to detect movements. Because metabolic and water-loss rates can increase with activity, these parameters were quantified during the periods when beetles were quiescent. Thus, measurements reflect standard metabolism at $20^{\circ}$ or $36^{\circ} \mathrm{C}$. All respirometry data were collected and analyzed using Datacan V software (Sable Systems). After measurement, beetles were flash frozen and stored at $-80^{\circ} \mathrm{C}$ until genotype analysis.

\section{Effects of Temperature on Laboratory Fecundity and Hsp70 Expression Level}

Effects of acclimation temperature on fecundity and Hsp expression were determined for females collected in June 2001 from Bluff Lake, located at an altitude of 3,200 $\mathrm{m}$ in the GL subdrainage of $\mathrm{BC}$. Beetles were transported in coolers to WMRS and sexes were separated. Beetles were acclimated to control conditions in the laboratory $\left(14 \mathrm{~L}: 10 \mathrm{D} ; 20^{\circ} \mathrm{C}\right.$ day, $4^{\circ} \mathrm{C}$ night) for $48 \mathrm{~h}$ before use. To begin the experiment, females were randomly placed in a petri dish with one male that was collected from the same site. Earlier field measurements of beetle body temperature showed that most individuals experienced temperatures that induce physiological stress for periods of 3-4 h each day, typically in the afternoon (Dahlhoff and Rank 2000). To mimic thermal experience in the field, 221 male-female pairs were maintained at $20^{\circ} \mathrm{C}$ for $4 \mathrm{~h}$ in the morning (8:00 a.m. to $12: 00$ p.m.); at either $20^{\circ}, 26^{\circ}$, or $32^{\circ} \mathrm{C}$ for 4 $\mathrm{h}$ in the afternoon (12:00-4:00 p.m.; the "temperature treatment”); at $20^{\circ} \mathrm{C}$ for $6 \mathrm{~h}$ in the evening (4:00-10:00 p.m.); and at $4^{\circ} \mathrm{C}$ for $10 \mathrm{~h}$ at night (10:00 p.m. to 8:00 a.m.). Willow sprigs were removed during the temperature treatment to minimize the potential confounding factor of heat-treating the willow. Willow sprigs were replaced with freshly collected plants every 1-2 d. Mating pairs were kept together throughout the experiment, and partners received the same temperature treatment. Eggs were counted twice daily, immediately before and after temperature treatment, by removing them from the petri dish and observing them under a dissecting microscope. Male mating activity was routinely monitored; males mated with females periodically throughout the experiment. After $24 \mathrm{~d}$, beetles were weighed, flash frozen, and stored at $-80^{\circ} \mathrm{C}$ until biochemical analysis. 


\section{Effects of Natural Climate on Fecundity}

Effects of climate variation on fecundity were measured for females collected in June 2002 from BC (Bluff Lake, 3,200 m altitude) and transplanted to similar elevation localities in BPC (Falls Site), RC (Mosquito Flat), and BC (Bluff Lake). Females were placed with one male in white tulle mesh bags on willow branches of replicate $S$. orestera $(n=13$ plants per drainage, six branches per plant). Egg clutches were removed from mesh bags twice a day, placed in plastic cups, and returned to the laboratory at WMRS, where egg number in each clutch was counted using methods described above. As in the laboratory experiment, male mating activity was monitored, and males mated with females throughout the experiment. At the end of the experiment, all beetles (and mesh bags) were removed from field sites and beetles were weighed, flash frozen, and stored at $-80^{\circ} \mathrm{C}$ until biochemical analysis.

\section{Biochemical Analysis}

Genotypes at three allozyme loci, PGI (EC 5.3.1.9), isocitrate dehydrogenase (IDH; EC 1.1.1.42), and phosphoglucomutase (PGM; EC 5.4.2.2), were determined by starch gel electrophoresis using established protocols (Rank 1992; Murphy et al. 1996). Expression levels of Hsp70 were determined for thorax tissue of females in laboratory and field fecundity experiments by Western blot analysis following published methods (Rank et al. 2007).

\section{Statistical Analysis}

All statistical analyses were performed in JMP IN, version 5.1 (SAS Institute, Cary, NC). For all experiments, analyses were initially performed for all three polymorphic loci scored. However, as has been observed in earlier studies, only the PGI genotype shows any significant effects in characteristics relevant to temperature adaptation. Analyses of other loci are therefore reported elsewhere (Fearnley 2003; Bruce 2005).

Population Structure of the Eastern Sierra Nevada. We used oneway ANOVA (main effect, subdrainage) to test for differences in PGI allele frequency among populations sampled in the six $\mathrm{BC}$ subdrainages.

Effects of Temperature on PGI Allele Frequency Variation. We analyzed changes in allele frequency using polytomous logistic regression with PGI frequency (per individual) as a dependent variable and life stage (overwintered adult, third-instar larvae, new adult), BC subdrainage (GL or CL), and population nested in a $\mathrm{BC}$ subdrainage as independent variables. Allele frequency was determined as the frequency of the PGI- 1 allele ( 0 for PGI 4-4 homozygotes, 0.5 for 1-4 heterozygotes, and 1 for 1-1 homozygotes). Polytomous logistic regression was the most appropriate approach because the dependent variable could take only three values and could not be analyzed with parametric statistics using continuous dependent variables. The main assumption of this logistic regression was that the error variable conforms to a multinomial distribution, which is considerably less restrictive than the assumption for continuous variables, which is that the error variable is normally distributed (Trexler and Travis 1993).

To determine how the environment relates to change in PGI frequency, we first calculated allele frequency at the population level. We then calculated the selection coefficient $(s)$ for the two intervals (overwintered adults to larvae, larvae to newly emerged adults) between the three collections, following standard methods for calculating relative fitness and selection coefficients from longitudinal genotype frequency data (Hartl and Clark 1997). If $s$ was positive, then genotype 1-1 was favored; if it was negative, then genotype 4-4 was favored. To determine which measure of temperature predicted the magnitude of the selection coefficient, regression models using mean minimum, mean average, and mean maximum temperatures were compared, and the variable with the highest $r^{2}$ value was selected (detailed in Fearnley 2003).

Metabolic Rate. Metabolic and water loss rates were analyzed using ANCOVA, with PGI genotype and treatment temperature as main effects and the PGI genotype-by-temperature interaction. Body mass was used as a covariate, rather than determining mass-specific metabolic rate, following recommendations of Packard and Boardman (1999). Five beetles measured at $20^{\circ} \mathrm{C}$ had negligible water loss rates $\left(<0.02 \mu \mathrm{L} \mathrm{h}^{-1}\right)$ and were removed from analysis. Each beetle was measured at either $20^{\circ}$ or $36^{\circ} \mathrm{C}$. $\mathrm{A}_{10}$ value was calculated from resulting mean metabolic rates for each genotype and temperature (Willmer et al. 2004), so no further statistical analyses were possible.

Fecundity Experiments. Results of the laboratory fecundity experiment were analyzed using repeated-measures ANCOVA, with acclimation temperature, genotype, and the interaction term as categorical fixed effects and total number of eggs laid over every $4 \mathrm{~d}$ as response variables (day 4, 8, 12, 16, 20, 24). Body mass, number of days to first egg clutch, and Hsp70 expression level were included as covariates. Two females that did not oviposit during the first $10 \mathrm{~d}$ of the experiment were excluded from analysis. Effects of acclimation temperature and PGI genotype on Hsp70 expression level were determined in a separate analysis using ANOVA. Results of field fecundity were analyzed using ANOVA, with transplant drainage and PGI genotype as main effects. Unlike laboratory fecundity, Hsp70 expression level was not a significant covariate in a preliminary ANCOVA, so it was not included in the final analysis.

\section{Results}

\section{Geographic Variation in PGI Allele Frequency}

The frequency of PGI allele 1 varies with latitude among drainages (Fig. 1; BPC $<\mathrm{BC}<\mathrm{RC}$ ), and the frequency of PGI allele 4 declines as the frequency of allele 1 rises. This north-to-south 

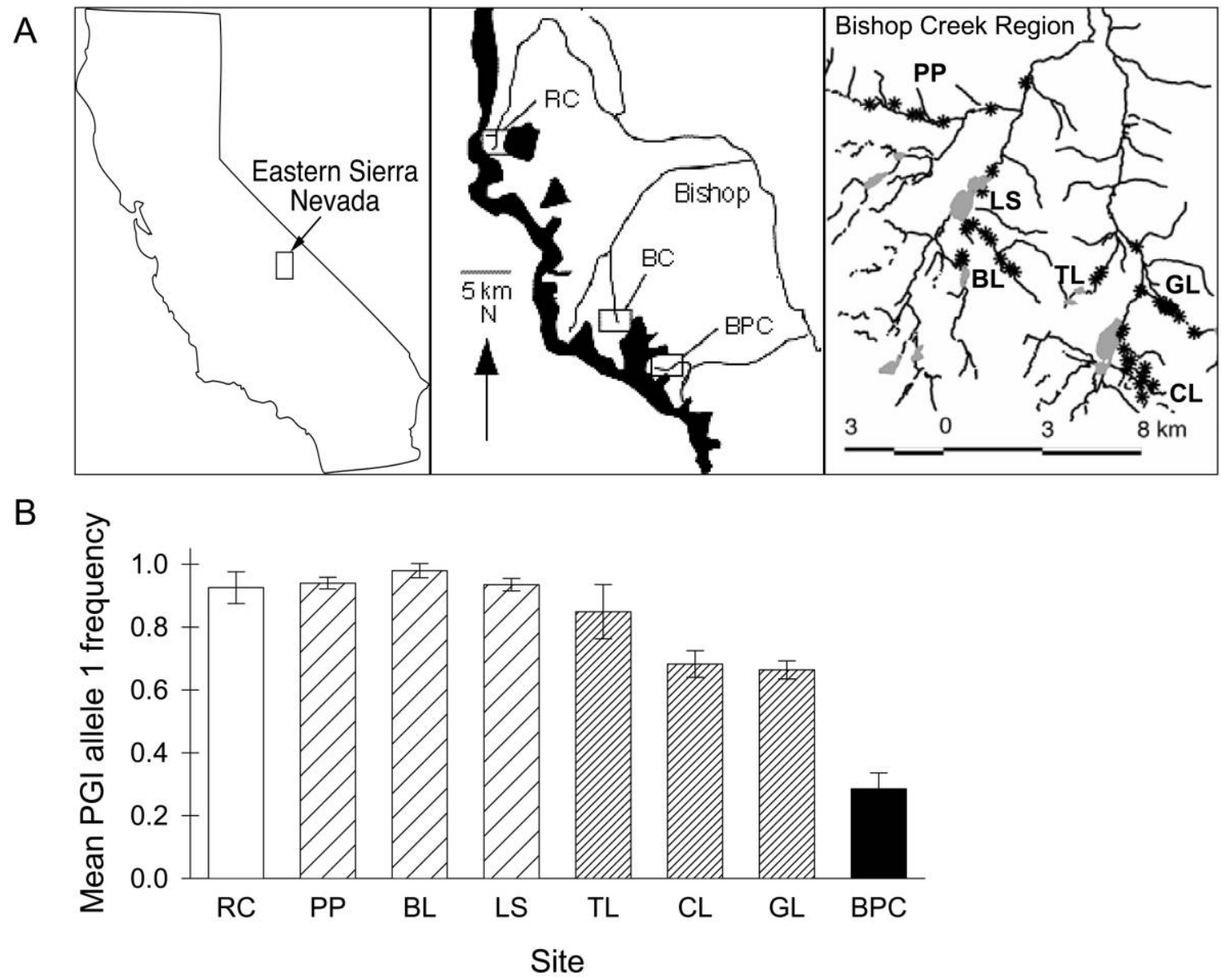

Figure 1. A, Location of Eastern Sierra Nevada, California, populations of the willow leaf beetle Chrysomela aeneicollis, including detailed location of Bishop Creek (BC) subpopulations (right). B, Allele frequency variation at the glycolytic enzyme locus phosphoglucose isomerase (PGI) along a north-south latitudinal gradient. Data shown are least squares means ( \pm SE) of PGI allele 1 frequencies for two to eight populations per site; $\mathrm{BC}$ subpopulations are shown as asterisks in A. Rock Creek (RC) is represented by open bars, northern $\mathrm{BC}$ by wide striped bars, southern BC by fine striped bars, and Big Pine Creek (BPC) by filled bars. Sample sizes and elevation ranges for BC subdrainages are given in Table 1. $P P=$ Paiute Pass; $L S=$ Lake Sabrina; $B L=$ Blue Lake; $T L=$ Tyee Lakes; $G L=$ Green Lake; $C L=$ Chocolate Lakes.

increase in frequency of PGI allele 4 is found among the six subdrainages surveyed in BC (one-way ANOVA; $F_{5,35}=17.0$, $P<0.001)$. The frequency of PGI allele 1 in north $\mathrm{BC}$ is similar to its frequency in $\mathrm{RC}$, and is greater than its frequency in south BC (Fig. 1B). Within south BC, PGI-1 is most common in the Tyee Lakes, which are in close proximity to north $\mathrm{BC}$, and PGI-4 is most common in GL populations, which are closest to BPC (Fig. 1B).

\section{Allele Frequency Change among Beetle Life Stages}

The frequency of PGI allele 1 in south BC populations was 0.67 for overwintered adults collected early in the summer ( $n=245)$; it increased by $9.7 \%$ (to 0.74$)$ in the second-instar larvae collected $60 \mathrm{~d}$ later $(n=248)$. However, the frequency of PGI allele 1 declined again by $11 \%$ (to 0.66 ) $30 \mathrm{~d}$ later, when new adults were collected ( $n=245)$. The PGI allele frequencies were significantly different among life-history stages $(G=7.0$, $\mathrm{df}=2, \quad P=0.03)$, as was variation among subdrainages ( $G=16.2$, $\mathrm{df}=5, P=0.006)$ and populations within a subdrainage $(G=6.3 \mathrm{df}=1, P=0.012)$. In contrast, there were no changes in allele frequency at IDH-2 or PGM among lifehistory stages, subdrainages, or populations within subdrainages (see Table A1 in the online edition of Physiological and Biochemical Zoology).

The magnitude of directional changes in PGI frequency was related to mean daily maximum temperature (Fig. 2). During the first part of summer, the increase in frequency of PGI allele 1 was related to mean maximum air temperature. In contrast, during the second part of summer, a decrease in frequency of allele 1 (with a concomitant increase in frequency of allele 4) was related to mean maximum air temperature. Mean maximum air temperatures were significantly higher in the second part of summer, when larvae were developing into new adults and allele 4 was becoming more frequent (matched-pairs $t$-test; $t=3.9, \mathrm{df}=4, P=0.009$ ). Preliminary regression models 


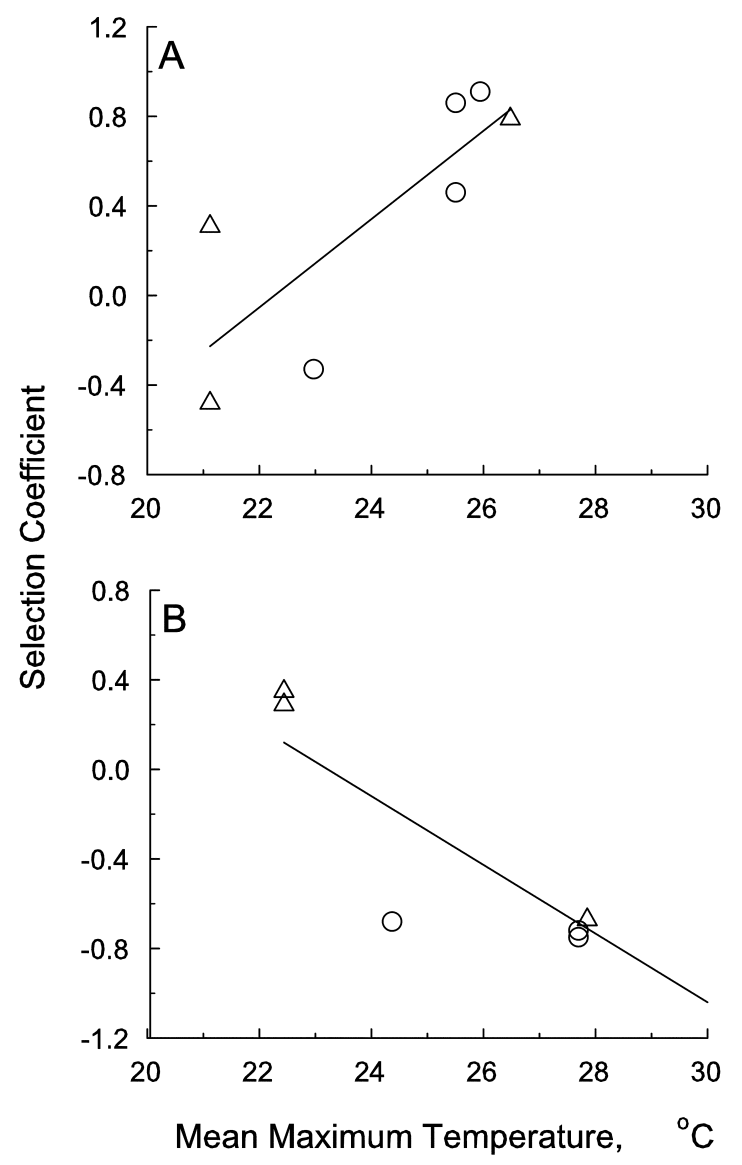

Figure 2. Effects of environmental temperature on phosphoglucose isomerase (PGI) selection coefficient $(s)$ in Bishop Creek. Data are selection coefficients for the frequency of PGI allele 1 between overwintered willow beetle adults and larvae $(A)$ and larvae and new adults $(B)$ at sites in Green Lake (triangles) and Chocolate Lakes (circles) regressed against mean maximal air temperature at each site when each life stage was present $\left(A: y=0.20 x-4.39, R^{2}=0.64, F=9.0\right.$, $\left.P=0.03 ; B: y=-0.15 x+3.57, R^{2}=0.77, F=17.0, P=0.01\right)$. A positive number indicates a positive selection coefficient for PGI allele 1.

showed that site elevation and mean minimum temperature were not related to the selection coefficient.

\section{Temporal and Spatial Changes in Beetle Abundance}

Populations of Chrysomela aeneicollis have shifted in elevation range and abundance during the past $9 \mathrm{yr}$. In 1998, after a late snowmelt and several years of above-average winter precipitation, beetles were most abundant at the lower portion of their elevation range (Table 2). Beetle abundance increased by $55 \%$ between 1998 and 2003 and stayed at these peak abundance levels from 2003 to 2006 (data not shown), coinciding with several winters of greater-than-average snow pack. However, even during these relatively wet years, summertime air temperatures were warmer at low elevations and beetle populations declined or disappeared at those sites while increasing in abun- dance at high-elevation sites. After the unusually dry winter of 2006-2007, typically wet meadows and pond sites were hot and dry by early June; beetle abundance decreased by $44 \%$ and shifted to higher elevations (Table 2; elevation-by-year interaction, $\left.F_{2,80}=3.8, P=0.026\right)$. By the end of the summer of 2007, populations had disappeared entirely throughout most of their previous elevation range in BPC and RC but were persistent at lower population sizes in most localities in BC.

\section{Relationship between PGI Genotype and Metabolic Rate}

Standard metabolic rate depended on measurement temperature and PGI genotype (Fig. 3; temperature: $F_{1,109}=44.6, P<$ 0.0001; temperature-by-PGI-genotype interaction: $F_{2,109}=3.0$, $P<0.05)$. Metabolic rate did not differ among genotypes at a moderate temperature $\left(20^{\circ} \mathrm{C}\right)$, but at $36^{\circ} \mathrm{C}$-near-maximal body temperature in nature-the metabolic rate of PGI 4-4 individuals was $45 \%$ greater than it was for PGI 1-1 or 1-4 individuals. The $\mathrm{Q}_{10}$ of metabolic rate varied twofold among genotypes. A $\mathrm{Q}_{10}$ value for PGI 4-4 genotypes was 3.24, compared with a value of 1.54 for the PGI 1-4 genotype and 1.66 for the PGI 1-1 genotype. All individuals lost water throughout the experiment, with larger beetles losing more water $\left(F_{1,109}=13.2, P<0.0005\right)$. Water loss rates were greater at $36^{\circ} \mathrm{C}$ $(1.73 \pm 1.7)$ than they were at $20^{\circ} \mathrm{C}\left(0.33 \pm 0.1 ; F_{1,109}=119\right.$, $P<0.0001)$ and did not vary among allozyme genotypes.

\section{Fecundity in the Laboratory}

Throughout the 24-d fecundity experiment, PGI 4-4 females laid fewer eggs than PGI 1-1 or PGI 1-4 females, and the rate of egg production of PGI 4-4 females declined more rapidly than it did for other PGI genotypes (Fig. 4A; Table A2 in the online edition of Physiological and Biochemical Zoology). Egg production was positively related to female body mass and negatively related to number of days before the first eggs were laid (Table A2, between-subjects factors). The relationships between these variables and egg production varied over the course of the experiment (Table A2, within-subjects by between-subjects factors interaction terms). Female Hsp70 expression levels, which were measured after $24 \mathrm{~d}$ of laboratory acclimation and egg laying, were positively correlated with total egg production (Fig. 4B).

Differences among PGI genotypes in total egg production were most pronounced for females maintained under control conditions for the entire experiment (Fig. 5A). Individuals with the PGI 1-1 genotype that were maintained under control conditions each afternoon $\left(20^{\circ} \mathrm{C}\right)$ laid more eggs than PGI 1-4 or PGI 4-4 control females. Females with the PGI 4-4 genotype that were maintained at $32^{\circ} \mathrm{C}$ each afternoon tended to lay more eggs than those maintained at $20^{\circ}$ or $26^{\circ} \mathrm{C}$, although differences in fecundity were not significant. Female Hsp70 expression levels measured at the end of the experiment were positively related to acclimation temperature $\left(F_{2,116}=6.2\right.$, 
Table 2: Persistences and abundances of Eastern Sierra Nevada beetle populations

\begin{tabular}{|c|c|c|c|c|c|c|c|}
\hline \multirow[b]{2}{*}{ Location, Year } & \multicolumn{7}{|c|}{ Elevation Range (m) } \\
\hline & $2,700-2,800$ & $2,850-2,930$ & $2,996-3,100$ & $3,130-3,200$ & $3,220-3,300$ & $3,310-3,450$ & $>3,500$ \\
\hline \multicolumn{8}{|l|}{ Big Pine Creek: } \\
\hline 1998 & 1 & 2 & 5 & 3 & 3 & - & - \\
\hline 2003 & - & 3 & 5 & 5 & 6 & 5 & - \\
\hline 2007 & - & - & - & 2 & 2 & 3 & 3 \\
\hline \multicolumn{8}{|c|}{ South Bishop Creek: } \\
\hline 1998 & 2 & 1 & 3 & 3 & 1 & 1 & - \\
\hline 2003 & - & 5 & 5 & 5 & 1 & 1 & - \\
\hline 2007 & - & 3 & 3 & 4 & 1 & 2 & - \\
\hline \multicolumn{8}{|l|}{ Rock Creek: } \\
\hline 1998 & 2 & 3 & 3 & 2 & - & - & - \\
\hline 2003 & 1 & 3 & 4 & 3 & 1 & - & - \\
\hline 2007 & - & - & 1 & 2 & 2 & 2 & - \\
\hline
\end{tabular}

Note. Data are relative abundance values of populations surveyed at peak early summer adult abundance in 1998, 2003, and 2007. Size of population is determined by a standardized visual survey of $25-100-\mathrm{m}^{2}$ areas of seven to 12 populations per drainage and is represented by the following scale: - : none observed; $1: 1-3 ; 2: 4-10 ; 3: 11-40 ; 4: 41-99 ; 5: 100-300 ; 6:>300$.

$P=0.003)$ and tended to be highest at $32^{\circ} \mathrm{C}$ for PGI $4-4$ females (Fig. 5B).

\section{Fecundity in Nature}

In nature, differences among PGI genotypes (but not other allozyme loci) in egg production among BC females depended on the drainage into which those females were transplanted (Fig. 6; genotype-by-drainage interaction, $F_{4,165}=2.8, P<$ 0.029). In RC, PGI 1-1 and PGI 1-4 females laid 32\% more eggs than PGI 4-4 females, whereas PGI 4-4 females laid 54\% more eggs than the other two genotypes in BPC. In BC, fecundity was high for all genotypes.

\section{Discussion}

Environmental physiologists have long predicted that components of reproductive success depend in part on an organism's physiological response to temperature. Here and elsewhere we have demonstrated that, in Chrysomela aeneicollis, variation at the PGI allozyme locus relates to physiological characters such as Hsp70 expression level, thermal tolerance, running speed, and metabolic rate. Observed relationships between PGI genotype and fecundity in the field and in the laboratory as reported here suggest that these physiological responses to temperature result in differential reproductive success among PGI genotypes. The finding that PGI frequencies fluctuate within a single generation shows that differences in reproductive success and survival, which are both critical components of population persistence, may result in rapid changes in genetic composition of natural populations. Finally, changes in C. aeneicollis abundance over $10 \mathrm{yr}$ (1998-2007) demonstrate that the range of this native insect has shifted upward in elevation, concomitant with climate change in the Sierra Nevada. Together with results of the field fecundity experiments, distribution and abundance data also suggest that beetles living in $\mathrm{BC}$ may be more tolerant of environmental change than those living in BPC or RC. Taken together, these data suggest that $C$. aeneicollis populations possess sufficient genetic variability to respond evolutionarily to a challenging thermal environment, but current conditions are causing local extinction at warmer, drier sites and at lower elevations.

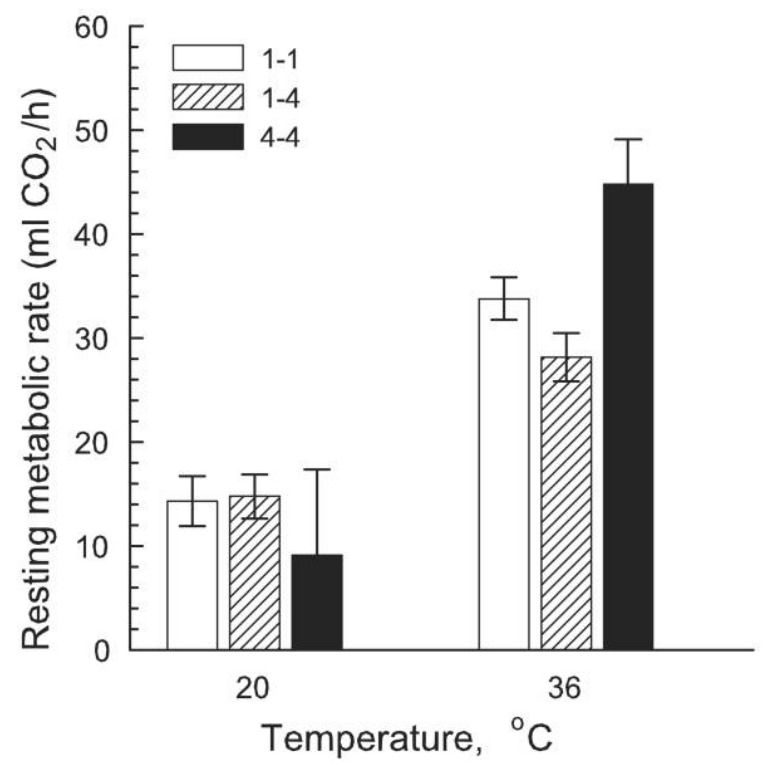

Figure 3. Differences among phosphoglucose isomerase (PGI) genotypes in the effect of temperature on metabolic rate. Data are least squares means $( \pm \mathrm{SE})$ of standard metabolic rate (indexed by rate of carbon dioxide production) for PGI 1-1 (open bars), PGI 1-4 (striped bars), and PGI 4-4 (filled bars). Subsequent figures follow the same fill pattern for PGI genotypes. Beetles were collected from Green Lake and Chocolate Lakes in Bishop Creek $\left(20^{\circ} \mathrm{C}: n=23,30,3 ; 36^{\circ} \mathrm{C}: n=\right.$ $31,24,7)$. Additional statistical analyses are reported in the text. 

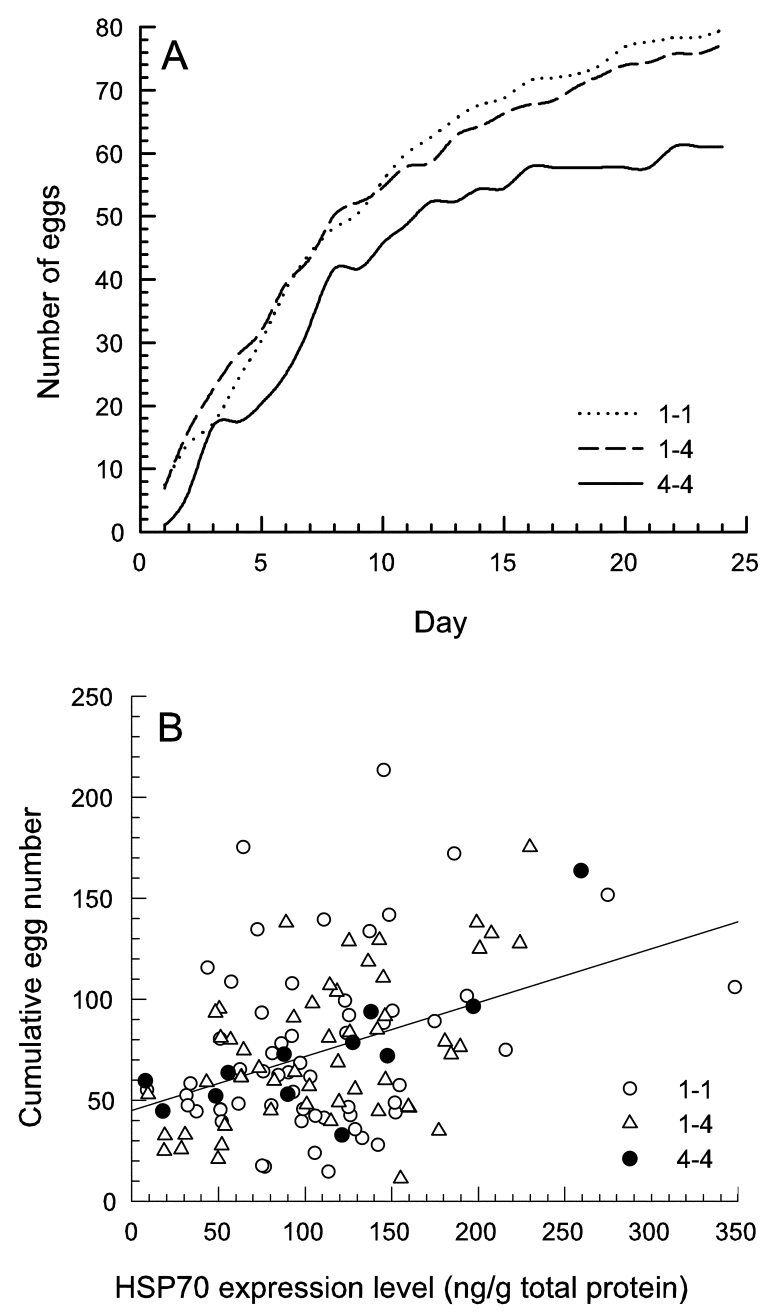

Figure 4. Differences among phosphoglucose isomerase (PGI) genotypes in number of eggs produced by Bishop Creek willow beetle females in the laboratory $(A)$ and relationship between $70-\mathrm{kD}$ heat shock protein (Hsp70) expression level at the end of the experiment and fecundity $(B)$. Data shown for $A$ are means of total number of eggs laid per day for PGI $1-1(n=63)$, PGI $1-4(n=57)$, and PGI $4-4(n=14)$ females. Statistical analysis is shown in Table A2 in the online edition of Physiological and Biochemical Zoology.

\section{Geographic Variation in PGI Frequency}

Chrysomela aeneicollis populations living in different drainages have distinct responses to seasonal fluctuations in environmental temperature and precipitation (Table 2). Whereas these unique responses may be the result of acclimatization or adaptation to local conditions, they may also be affected by genetic differences among populations. Findings presented here reveal how geographic variation at PGI is structured among populations within $\mathrm{BC}$, which lies between $\mathrm{BPC}$ and RC (Fig. 1). In general, populations in south $\mathrm{BC}$ are more genetically similar to populations in BPC (high frequency of PGI allele 4), whereas those in north $\mathrm{BC}$ are more similar to populations in RC (high frequency of PGI allele 1). Within south BC, PGI allele 4 fre- quencies are greatest in populations that are near BPC (GL and $\mathrm{CL})$. One explanation for this pattern is that south $\mathrm{BC}$ represents a zone of contact between two genetically distinct lineages of $C$. aeneicollis, one from the south and another from the north. Studies of variation at mitochondrial DNA loci (COI and COII) are consistent with this hypothesis (Fearnley 2003). Populations at $\mathrm{BC}$ may ultimately harbor more genetic diversity than other drainages and may thus be more resilient to impending changes in climate.

\section{Seasonal Changes in PGI Frequency and Relationship to Environmental Temperature}

The current distribution of alleles in south BC probably results from a balance between historical migration and natural se-
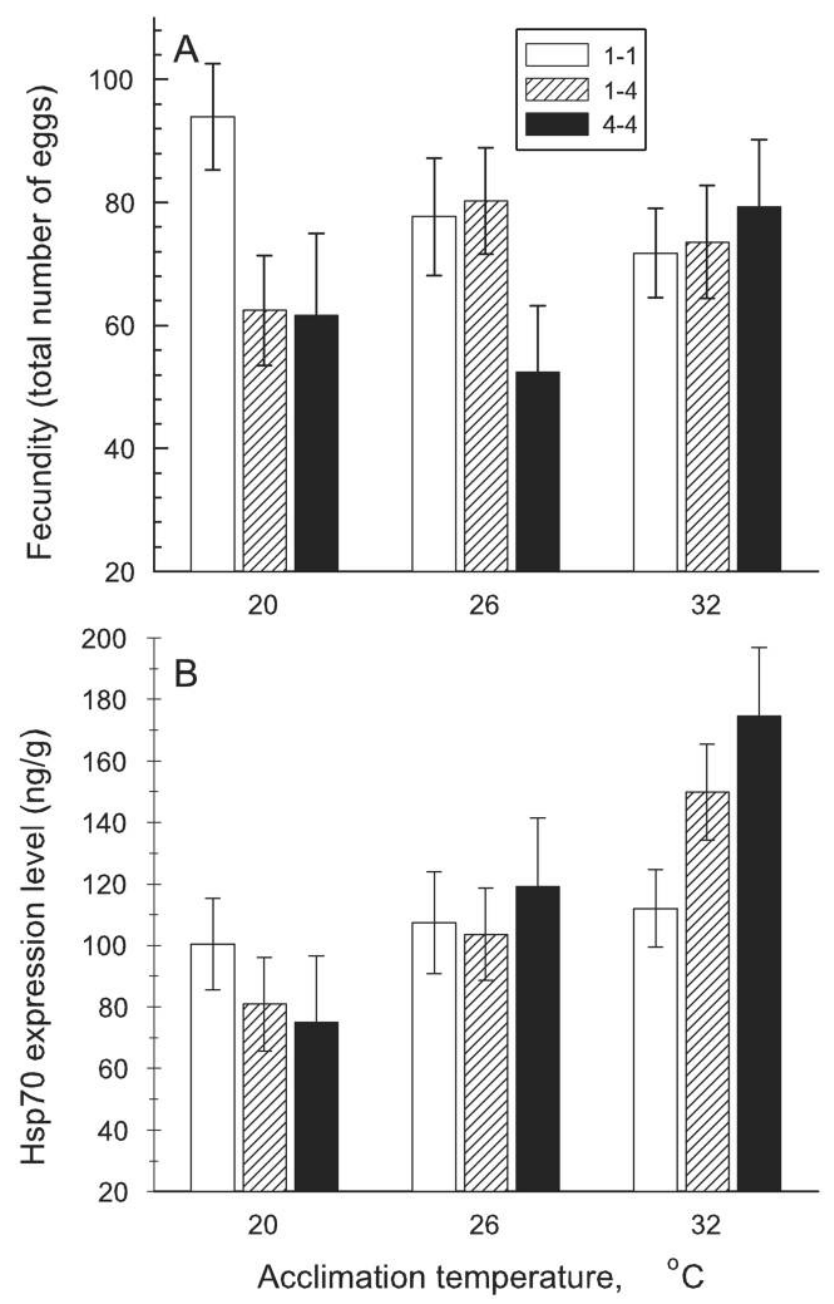

Figure 5. Effects of phosphoglucose isomerase (PGI) genotype and acclimation temperature on egg production and $70-\mathrm{kD}$ heat shock protein (Hsp70) expression level for Bishop Creek willow beetle females. Data are least squares means $( \pm \mathrm{SE})$ of total number of eggs produced $(A)$ and Hsp70 expression level $(B)$ after $24 \mathrm{~d}$ of laboratory acclimation to different temperatures. Sample sizes are as follows (for PGI 1-1, 1-4, and 4-4, respectively): $20^{\circ} \mathrm{C}, n=19,18,4 ; 26^{\circ} \mathrm{C}, n=$ $15,18,5 ; 32^{\circ} \mathrm{C}, n=25,17,5$. Additional statistical analysis is described in text. 


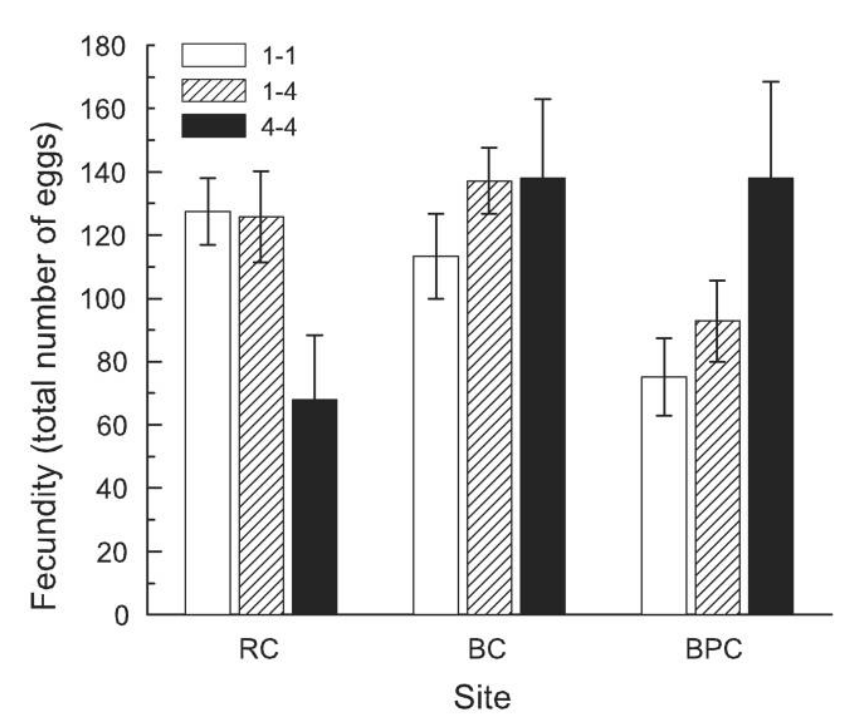

Figure 6. Differences among phosphoglucose isomerase (PGI) genotypes in fecundity of Bishop Creek (BC) willow beetle females transplanted to drainages differing in local climate. Data are least squares means $( \pm S E)$ of total number of eggs produced in nature. Sample sizes are as follows (for PGI 1-1, 1-4, and 4-4, respectively): Rock Creek (RC), $n=34,18,9$; BC, $n=21,34,6$; Big Pine Creek (BPC), $n=$ $25,23,4$. Additional statistical analysis is described in text.

lection. Previous studies have shown that allele frequencies shifted toward PGI allele 1 in south BC after several years of cool, wet conditions (Rank and Dahlhoff 2002). In this study, the frequency of PGI allele 1 increased during early summer 2001 (overwintered adults to larvae), whereas PGI allele 4 increased during mid- to late summer 2001 (larvae to new adults; Fig. 2). These findings suggest that reproductive success of south BC adults possessing PGI allele 1 was greater than that of those possessing allele 4 but that survival of larvae possessing allele 4 was greater than that of those possessing allele 1. Because each shift was related to maximum air temperature, populations that shifted most toward allele 1 in early summer tended to experience the greatest subsequent shift back toward allele 4 . One possible explanation for this pattern, which is consistent with physiological data (Dahlhoff and Rank 2007; Rank et al. 2007), is that PGI allele 1 was favored during the moderately warm conditions that prevailed when overwintered adults were reproducing but that PGI allele 4 was favored when maximum air temperatures were significantly hotter in the latter part of the summer. Studies of other organisms also suggest that alleles favored at one life-history stage can be disadvantageous at another, in part due to changes in environmental conditions (Johannesson et al. 1995; Johannesson 2003). Thus, fluctuating selection on enzyme loci, such as is apparent in C. aeneicollis populations, may occur more often than is generally reported (Mitton 1997; Ward et al. 2004). Future studies are planned that will allow us to determine whether fluctuating selection is operating at the PGI locus and whether it is an important component of population persistence in Sierra willow beetle populations.

Relationship between Metabolic Rate and Variation at PGI

The relationship between PGI variation and metabolic rate suggests that individuals possessing the PGI 1 allele are less sensitive to thermal variation (have a lower $\mathrm{Q}_{10}$ value) than PGI 4-4 individuals but that 4-4 individuals have the highest metabolic rates (consistent with enhanced performance) at temperatures near the maximum measured in nature $\left(36^{\circ} \mathrm{C}\right.$; Fig. 3$)$. This pattern is atypical, as populations or species with high $\mathrm{Q}_{10}$ values for metabolic rate are often the most thermally sensitive or cold acclimated (Berrigan and Patridge 1997; Nielsen et al. 1999; Chown and Nicolson 2004). However, the findings reported here are not unique, as elevated metabolic rate after acclimation to warm temperatures has been reported in another species of cold-temperate beetle (Terblanche et al. 2005). One possible explanation for the patterns in metabolic rate reported here is that genotypes responded differently to experimental starvation and subsequent heat stress. Beetles were maintained at $20^{\circ} \mathrm{C}$ and fed ad lib. on willow after collection but were deprived of food for 4-6 d before metabolic rate measurements were performed, to reduce confounding effects of feeding variation on metabolic rate (Willmer et al. 2004). Our earlier studies, as well as laboratory fecundity data reported here, suggest that PGI 4-4 genotypes are less active (e.g., they run slower, lay fewer eggs) when maintained at $20^{\circ} \mathrm{C}$ than individuals possessing PGI allele 1 . These data suggest that PGI 4-4 individuals have lower metabolic demands at moderate temperatures and thus may have more energetic reserves to maintain elevated metabolic rate when challenged with a stressful temperature $\left(36^{\circ} \mathrm{C}\right)$ than other genotypes would. Clearly, PGI plays a significant role in insect glucose metabolism (Watt et al. 1985; Staples and Suarez 1997; Haag et al. 2005). Whether functional differences among PGI allozymes reported in earlier studies (Dahlhoff and Rank 2000, 2007) are the ultimate cause of differences in metabolic activity among PGI genotypes in C. aeneicollis is not known, but it is the focus of current and future studies.

\section{Laboratory Fecundity and the Heat Shock Response}

In the laboratory, fecundity of females maintained at moderate temperatures $\left(20^{\circ}\right.$ and $\left.26^{\circ} \mathrm{C}\right)$ was greatest for PGI 1-1 and PGI 1-4 genotypes and was reduced for PGI 4-4 genotypes (Fig. 4). This experiment was conducted over the range of acclimation temperatures expected to produce differences among PGI genotypes in Hsp70 expression level (Fig. 5); as predicted, PGI 4-4 individuals had higher thorax Hsp70 levels at the highest acclimation temperature $\left(32^{\circ} \mathrm{C}\right)$. However, there was no overall decline in fecundity with increased temperature, and we found that fecundity was positively related to thorax Hsp70 expression regardless of acclimation temperature. This was initially surprising, as most studies have suggested that upregulation of the 
heat shock response ultimately results in a performance or fitness cost (Krebs and Feder 1998; Krebs and Holbrook 2001; Sorensen et al. 2003; Pedersen et al. 2005). However, the Hsp70 expression levels we report here were lower than those for beetles that were subjected to acute stress exposures in nature or in the laboratory. In 1998, rapid snowmelt followed by weeks of hot, sunny weather in the Eastern Sierra Nevada led to in situ Hsp70 expression levels that were three- to fourfold greater than those reported here (Dahlhoff and Rank 2000), as did laboratory measurements of differences in $\mathrm{CT}_{\max }$ among PGI genotypes (Neargarder et al. 2003). These lower Hsp70 expression levels, along with a positive relationship between thorax Hsp70 expression level and egg production, suggest that we may have observed upregulation of non-stress-inducible (cognate) forms of Hsp70. If this is the case, it is possible that we detected isoforms of Hsp70 specifically upregulated to protect cellular machinery critical for activities associated with reproduction, as has been reported in other systems (Sambucetti et al. 2005; Kellermann et al. 2007).

\section{Fecundity in Nature and Implications for Population Persistence}

Differences in fecundity among PGI genotypes in nature corresponded to the natural distribution of PGI alleles in the three main study drainages (Fig. 6). This intriguing result provides evidence that the current distribution of allele frequencies results, at least in part, from natural selection. In the warm, southern drainage, BPC, where PGI allele 4 is most common, PGI 4-4 genotypes had the highest fecundity, whereas in the cooler, northern drainage, $\mathrm{RC}$, fecundity was greater for females possessing the most common allele occurring there, PGI allele 1. Fecundity of all three genotypes was high in BC. Most reciprocal transplant studies in terrestrial systems have been conducted using plants (Brady et al. 2005; Sambatti and Rice 2006; Espeland and Rice 2007). These findings suggest that terrestrial animal populations can also become rapidly acclimatized to local conditions.

These data also have implications for persistence of beetle populations in the Eastern Sierra Nevada. Individuals in BC who are homozygous for PGI allele 4 lay more eggs where it is warmest, appear to survive best during the warmest part of the growing season, and have higher metabolic rates at $36^{\circ} \mathrm{C}$, the highest body temperatures observed in nature. In contrast, individuals homozygous for allele 1 lay the most eggs overall under mild $\left(20^{\circ}, 26^{\circ} \mathrm{C}\right)$ or moderately stressful $\left(32^{\circ} \mathrm{C}\right)$ laboratory conditions, have the highest fecundity in the coolest drainage, appear to survive and reproduce best in the cooler part of the growing season, and have metabolic rates that are less temperature sensitive than PGI 4-4 homozygotes. Heterozygotes are intermediate in thermal tolerance of metabolism and fecundity. Populations in $\mathrm{BC}$ may be able to tolerate a variable climate more readily than other populations because of a broader thermal tolerance range indexed by the PGI polymorphism.

\section{Conclusions}

These data begin to close gaps in our knowledge about the relationship between population persistence and species distribution and the genetic properties of organisms that live in stressful environments on the edge of their biogeographic range. Our studies show that a genetic polymorphism in a native species is associated with traits that confer temperature adaptation and that frequencies of the most common alleles at this polymorphic locus fluctuate in the short and medium term. These fluctuations also relate to differences in thermal microclimate. Nevertheless, we still know little about the populationscale consequences of genetic variation at PGI, and this gap hinders our ability to predict how populations will respond to increasingly variable thermal conditions predicted by most current models of climate change. We are continuing to document changes in these populations to preserve a long-term data set, gaining insight into effects of climate change on natural populations. Future studies will directly relate population dynamics to the level of physiological stress on and genetic composition of $C$. aeneicollis populations to address these important questions.

\section{Acknowledgments}

We sincerely thank the two anonymous reviewers whose insightful and detailed comments significantly improved this manuscript. We gratefully acknowledge J. Zatorski, P. Kudoo, B. Becker, C. Dick, J. Freeto, T. Goodwin, S. Hurley, M. McCarthy, and K. Mulkey for hiking many miles to locate beetle populations. We also thank C. Bayless, B. Butzman, E. Strode, J. Hollister, and A. Keil for the same, as well as for their countless hours spent measuring fecundity and mating success in the laboratory and field. Thanks to D. Hollis for his assistance in obtaining genotypes for beetles in the metabolic rate experiment. We thank the director and staff of the White Mountain Research Station (WMRS; Bishop, CA) for providing laboratory and housing facilities. We are especially grateful to M. Elekonich of University of Nevada, Las Vegas, for allowing A.G.G. and E.P.D. the use of her laboratory to measure beetle metabolic rates. This research was supported by a National Science Foundation award (IBN-RUI-0078464/0078659) to E.P.D. and N.E.R., a Santa Clara University (SCU) Presidential Research grant to E.P.D., an SCU Undergraduate Research Mentorship award that supported M. McCarthy and C. Dick, a mini-grant from WMRS for housing support of D.A.B. and S.L.F., and a Sonoma State University Undergraduate Research Grant to D. Hollis.

\section{Literature Cited}

Anestis A., A. Lazou, H.O. Portner, and B. Michaelidis. 2007. Behavioral, metabolic, and molecular stress responses of marine bivalve Mytilus galloprovincialis during long-term accli- 
mation at increasing ambient temperature. Am J Physiol Reg Integr Comp Physiol 293:R911-R921.

Angilletta M.J., Jr., A.F. Bennett, H. Guderley, C.A. Navas, F. Seebacher, and R.S. Wilson. 2006. Coadaptation: a unifying principle in evolutionary thermal biology. Physiol Biochem Zool 79:282-294.

Balanya J., J.M. Oller, R.B. Huey, G.W. Gilchrist, and L. Serra. 2006. Global genetic change tracks global climate warming in Drosophila subobscura. Science 313:1773-1775.

Berrigan D. and L. Patridge. 1997. Influence of temperature and activity on the metabolic rate of adult Drosophila melanogaster. Comp Biochem Physiol A 118:1301-1307.

Bertness M.D. and P.J. Ewanchuk. 2002. Latitudinal and climate-driven variation in the strength and nature of biological interactions in New England salt marshes. Oecologia 132: 392-401.

Boggs C.L. and K.D. Freeman. 2005. Larval food limitation in butterflies: effects on adult resource allocation and fitness. Oecologia 144:353-361.

Bradshaw W.E. and C.M. Holzapfel. 2006. Climate change: evolutionary response to rapid climate change. Science 312: 1477-1478.

Bradshaw W.E., P.A. Zani, and C.M. Holzapfel. 2004. Adaptation to temperate climates. Evolution 58:1748-1762.

Brady K.U., A.R. Kruckeberg, and H.D. Bradshaw. 2005. Evolutionary ecology of plant adaptation to serpentine soils. Annu Rev Ecol Evol Syst 36:243-266.

Brooker R.W., F.T. Maestre, R.M. Callaway, C.L. Lortie, L.A. Cavieres, G. Kunstler, P. Liancourt, et al. 2008. Facilitation in plant communities: the past, the present, and the future. J Ecol 96:18-34.

Bruce D.A. 2005. Effects of PGI Genotype and Temperature on Fecundity, Mating Success and Running Speed of a Sierra Willow Leaf Beetle. MS thesis. Sonoma State University, Rohnert Park, CA.

Chamaille-Jammes S., M. Massot, P. Aragon, and J. Clobert. 2006. Global warming and positive fitness response in mountain populations of common lizards Lacerta vivipara. Global Change Biol 12:392-402.

Chown S.L. and S. Nicolson. 2004. Insect Physiological Ecology: Mechanisms and Patterns. Oxford University Press, Oxford.

Crozier L. and G. Dwyer. 2006. Combining populationdynamic and ecophysiological models to predict climateinduced insect range shifts. Am Nat 167:853-866.

Dahlhoff E.P. 2004. Biochemical indicators of stress and metabolism: applications for marine ecological studies. Annu Rev Physiol 66:183-207.

Dahlhoff E.P. and N.E. Rank. 2000. Functional and physiological consequences of genetic variation at phosphoglucose isomerase: heat shock protein expression is related to enzyme genotype in a montane beetle. Proc Natl Acad Sci USA 97: 10056-10061.

- 2007. The role of stress proteins in responses of a willow leaf beetle to environmental temperature variation. J Biosci 32:477-488.
Diffenbaugh N.S., J.S. Pal, R.J. Trapp, and F. Giorgi. 2005. Finescale processes regulate the response of extreme events to global climate change. Proc Natl Acad Sci USA 102:1577415778.

Dillon M.E., L.R.Y. Cahn, and R.B. Huey. 2007. Life history consequences of temperature transients in Drosophila melanogaster. J Exp Biol 210:2897-2904.

Eanes W.F. 1999. Analysis of selection on enzyme polymorphisms. Annu Rev Ecol Syst 30:301-326.

Easterling D.R., G.A. Meehl, C. Parmesan, S.A. Changnon, T.R. Karl, and L.O. Mearns. 2000. Climate extremes: observations, modeling, and impacts. Science 289:2068-2074.

Ellis A.M. and E. Post. 2004. Population response to climate change: linear vs. non-linear modeling approaches. BMC Ecol 4:2.

Erasmus B.F.N., A.S. Van Jaarsveld, S.L. Chown, M. Kshatriya, and K.J. Wessels. 2002. Vulnerability of South African animal taxa to climate change. Global Change Biol 8:679-693.

Espeland E.K. and K.J. Rice. 2007. Facilitation across stress gradients: the importance of local adaptation. Ecology 88: 2404-2409.

Fearnley S.L. 2003. Adaptation at an Enzyme Locus in Chrysomela aeneicollis: Situating the PGI Polymorphism in a Functional and Historical Context. MS thesis. Sonoma State University, Rohnert Park, CA.

Feder M.E., A.F. Bennett, and R.B. Huey. 2000. Evolutionary physiology. Annu Rev Ecol Syst 31:315-341.

Feder M.E. and G.E. Hofmann. 1999. Heat-shock proteins, molecular chaperones and the heat-shock response: evolutionary and ecological physiology. Annu Rev Physiol 61:243282.

Feder M.E. and R.A. Krebs. 1997. Ecological and evolutionary physiology of heat shock proteins and the stress response in Drosophila: complementary insights from genetic engineering and natural variation. Pp. 155-173 in R. Bijlsma and V. Loeschcke, eds. Environmental Stress, Adaptation, and Evolution. Birkhäuser, Basel.

Franklin J.F. and J.A. MacMahon. 2000. Ecology: messages from a mountain. Science 288:1183-1185.

Garland T., Jr., and S.A. Kelly. 2006. Phenotypic plasticity and experimental evolution. J Exp Biol 209:2344-2361.

Ghalambor C.K., J.K. McKay, S.P. Carroll, and D.N. Reznick. 2007. Adaptive versus non-adaptive phenotypic plasticity and the potential for contemporary adaptation in new environments. Funct Ecol 21:394-407.

Gilman S.E., D.S. Wethey, and B. Helmuth. 2006. Variation in the sensitivity of organismal body temperature to climate change over local and geographic scales. Proc Natl Acad Sci USA 103:9560-9565.

Gworek J.R., S.B.V. Wall, and P.F. Brussard. 2007. Changes in biotic interactions and climate determine recruitment of Jeffrey pine along an elevation gradient. For Ecol Manag 239: 57-68.

Haag C.R., M. Saastamoinen, J.H. Marden, and I. Hanski. 2005. 
A candidate locus for variation in dispersal rate in a butterfly metapopulation. Proc R Soc B 272:2449-2456.

Hampe A. and R.J. Petit. 2005. Conserving biodiversity under climate change: the rear edge matters. Ecol Lett 8:461-467.

Hanski I. and I. Saccheri. 2006. Molecular-level variation affects population growth in a butterfly metapopulation. PLoS Biol 4:719-726.

Harley C.D.G., A.R. Hughes, K.M. Hultgren, B.G. Miner, C.J.B. Sorte, C.S. Thornber, L.F. Rodriguez, L. Tomanek, and S.L. Williams. 2006. The impacts of climate change in coastal marine systems. Ecol Lett 9:228-241.

Hartl D.L. and A.G. Clark 1997. Principles of Population Genetics. Sinauer, Sunderland, MA.

Hayhoe K., D. Cayan, C.B. Field, P.C. Frumhoff, E.P. Maurer, N.L. Miller, S.C. Moser, et al. 2004. Emissions pathways, climate change, and impacts on California. Proc Natl Acad Sci USA 101:12422-12427.

Helmuth B., C.D.G. Harley, P.M. Halpin, M. O’Donnell, G.E. Hofmann, and C.A. Blanchette. 2002. Climate change and latitudinal patterns of intertidal thermal stress. Science 298: 1015-1017.

Hill J.K., C.D. Thomas, R. Fox, M.G. Telfer, S.G. Willis, J. Asher, and B. Huntley. 2002. Responses of butterflies to twentieth century climate warming: implications for future ranges. Proc R Soc B 269:2163-2171.

Hodkinson I. 2005. Terrestrial insects along elevation gradients: species and community responses to altitude. Biol Rev 80: 489-513.

Hoffmann F. and U. Rinas. 2001. On-line estimation of the metabolic burden resulting from the synthesis of plasmidencoded and heat-shock proteins by monitoring respiratory energy generation. Biotechnol Bioeng 76:333-340.

Hofmann G.E. and G.N. Somero. 1995. Evidence for protein damage at environmental temperatures: seasonal changes in levels of ubiquitin conjugates and HSP70 in the intertidal mussel Mytilus trossulus. J Exp Biol 198:1509-1518.

Inouye D.W., B. Barr, K.B. Armitage, and B.D. Inouye. 2000. Climate change is affecting altitudinal migrants and hibernating species. Proc Natl Acad Sci USA 97:1630-1633.

IPCC (International Panel on Climate Change). 2007. Climate Change 2007: Impacts, Adaptation and Vulnerability. Working Group II Contribution to the Fourth Assessment Report of the IPCC. Cambridge University Press, Cambridge.

Johannesson K. 2003. Evolution in Littorina: ecology matters. J Sea Res 49:107-117.

Johannesson K., B. Johannesson, and U. Lundgren. 1995. Strong natural selection causes microscale allozyme variation in a marine snail. Proc Natl Acad Sci USA 92:2602-2606.

Karlsson B. and C. Wiklund. 2005. Butterfly life history and temperature adaptations: dry open habitats select for increased fecundity and longevity. J Anim Ecol 74:99-104.

Kellermann V.M., A.A. Hoffmann, and C.M. Sgro. 2007. Hsp90 inhibition and the expression of phenotypic variability in the rainforest species Drosophila birchii. Biol J Linn Soc 92:457465.
Krebs R.A. and M.E. Feder. 1997. Deleterious consequences of Hsp70 overexpression in Drosophila melanogaster larvae. Cell Stress Chaperones 2:60-71.

. 1998. Hsp70 and larval thermotolerance in Drosophila melanogaster: how much is enough and when is more too much? J Insect Physiol 44:1091-1101.

Krebs R.A. and S.H. Holbrook. 2001. Reduced enzyme activity following Hsp70 overexpression in Drosophila melanogaster. Biochem Genet 39:73-82.

Leonard G.H. 2000. Latitudinal variation in species interactions: a test in the New England rocky intertidal zone. Ecology 81: 1015-1030.

Lesser M.P. and V.A. Kruse. 2004. Seasonal temperature compensation in the horse mussel, Modiolus modiolus: metabolic enzymes, oxidative stress and heat shock proteins. Comp Biochem Physiol A 137:495-504.

Lester S.E., S.D. Gaines, and B.P. Kinlan. 2007. Reproduction on the edge: large-scale patterns of individual performance in a marine invertebrate. Ecology 88:2229-2239.

Li Y., J.G. Qin, C.A. Abbott, X.X. Li, and K. Benkendorff. 2007. Synergistic impacts of heat shock and spawning on the physiology and immune health of Crassostrea gigas: an explanation for summer mortality in Pacific oysters. Am J Physiol Regul Integr Comp Physiol 293:R2353-R2362.

Loeschcke V., R.A. Krebs, J. Dahlgaard, and P. Michalak. 1997. High-temperature stress and the evolution of thermal resistance in Drosophila. Pp. 175-190 in R. Bijlsma and V. Loeschcke, eds. Environmental Stress, Adaptation, and Evolution. Birkhäuser, Basel.

McLaughlin J.F., J.J. Hellmann, C.L. Boggs, and P.R. Ehrlich. 2002. Climate change hastens population extinctions. Proc Natl Acad Sci USA 99:6070-6074.

McMillan D.M., S.L. Fearnley, N.E. Rank, and E.P. Dahlhoff. 2005. Natural temperature variation affects larval survival, development and Hsp70 expression in a leaf beetle. Funct Ecol 19:844-852.

Miller N.L., K.E. Bashford, and E. Strem. 2003. Potential impacts of climate change on California hydrology. J Am Water Res Assoc 39:771-784.

Mitton J.B. 1997. Selection in Natural Populations. Oxford University Press, New York.

Murphy R.W., J.W. Sites, D.G. Buth, and C.H. Haufler. 1996. Proteins: isozyme electrophoresis. Pp. 51-120 in D.M. Hillis, C. Moritz, and B.K. Mable, eds. Molecular Systematics. Sinauer, Sunderland, MA.

Musolin D.L. 2007. Insects in a warmer world: ecological, physiological and life-history responses of true bugs (Heteroptera) to climate change. Global Change Biol 13:1565-1585.

Neargarder G.G., E.P. Dahlhoff, and N.E. Rank. 2003. Variation in thermal tolerance is linked to phosphoglucose isomerase genotype in a montane leaf beetle. Funct Ecol 17:213-221.

Nielsen M.G., G.W. Elmes, and V.E. Kipyatkov. 1999. Respiratory $\mathrm{Q}_{10}$ varies between populations of two species of $\mathrm{Myr}$ mica ants according to the latitude of their sites. J Insect Physiol 45:559-564. 
Nussey D.H., A.J. Wilson, and J.E. Brommer. 2007. The evolutionary ecology of individual phenotypic plasticity in wild populations. J Evol Biol 20:831-844.

Packard G.C. and T.J. Boardman. 1999. The use of percentages and size-specific indices to normalize physiological data for variation in body size: wasted time, wasted effort? Comp Biochem Physiol A 122:37-44.

Parmesan C. 2006. Ecological and evolutionary responses to recent climate change. Annu Rev Ecol Evol Syst 37:637-669.

Parmesan C., N. Ryrholm, C. Stefanescu, J.K. Hill, C.D. Thomas, H. Descimon, B. Huntley, et al. 1999. Poleward shifts in geographical ranges of butterfly species associated with regional warming. Nature 399:579-583.

Parmesan C. and G. Yohe. 2003. A globally coherent fingerprint of climate change impacts across natural systems. Nature 421 : 37-42.

Pearson R. and T. Dawson. 2003. Predicting the impacts of climate change on the distribution of species: are bioclimate envelope models useful? Global Ecol Biogeogr 12:361-371.

Pedersen K.S., T.N. Kristensen, and V. Loeschcke. 2005. Effects of inbreeding and rate of inbreeding in Drosophila melanogaster: Hsp70 expression and fitness. J Evol Biol 18:756-762.

Peterson A.T. 2003. Projected climate change effects on Rocky Mountain and Great Plains birds: generalities of biodiversity consequences. Global Change Biol 9:647-655.

Petes L.E., B.A. Menge, and G.D. Murphy. 2007. Environmental stress decreases survival, growth, and reproduction in New Zealand mussels. J Exp Mar Biol Ecol 351:83-91.

Rank N.E. 1992. A hierarchical analysis of genetic differentiation in a montane leaf beetle (Chrysomela aeneicollis). Evolution 46:1097-1111.

- 1994. Host plant effects on larval survival in a salicinusing leaf beetle Chrysomela aeneicollis (Coleoptera: Chrysomelidae). Oecologia 97:342-353.

Rank N.E., D.A. Bruce, D.M. McMillan, C. Barclay, and E.P. Dahlhoff. 2007. Phosphoglucose isomerase genotype affects running speed and heat shock protein expression after exposure to extreme temperatures in a montane willow beetle. J Exp Biol 210:750-764.

Rank N.E. and E.P. Dahlhoff. 2002. Allele frequency shifts in response to climate change and physiological consequences of allozyme variation in a montane insect. Evolution 56: 2278-2289.

Reed D.H., A.C. Nicholas, and G.E. Stratton. 2007. Inbreeding levels and prey abundance interact to determine fecundity in natural populations of two species of wolf spider. Conserv Genet 8:1061-1071.

Reznick D. and J. Travis. 1996. The empirical study of adaptation in natural populations. Pp. 243-289 in M. Rose and G.V. Lauder, eds. Adaptation. Academic Press, London.

Riddoch B.J. 1993. The adaptive significance of electrophoretic mobility in phosphoglucose isomerase (PGI). Biol J Linn Soc 50:1-17.

Sagarin R.D., J.P. Barry, S.E. Gilman, and C.H. Baxter. 1999.
Climate-related change in an intertidal community over short and long time scales. Ecol Monogr 69:465-490.

Sambatti J.B.M. and K.J. Rice. 2006. Local adaptation, patterns of selection, and gene flow in the Californian serpentine sunflower (Helianthus exilis). Evolution 60:696-710.

Sambucetti P., J.G. Sorensen, V. Loeschcke, and F.M. Norry. 2005. Variation in senescence and associated traits between sympatric cactophilic sibling species of Drosophila. Evol Ecol Res 7:915-930.

Smiley J.T. and N.E. Rank. 1986. Predator protection versus rapid growth in a montane leaf beetle. Oecologia 70:106112.

Sorensen J.G., T.N. Kristensen, and V. Loeschcke. 2003. The evolutionary and ecological role of heat shock proteins. Ecol Lett 6:1025-1037.

Sorensen J.G. and V. Loeschcke. 2002. Decreased heat-shock resistance and down-regulation of Hsp70 expression with increasing age in adult Drosophila melanogaster. Funct Ecol 16:379-384.

Staples J.F. and R.K. Suarez. 1997. Honeybee flight muscle phosphoglucose isomerase: matching enzyme capacities to flux requirements at a near-equilibrium reaction. J Exp Biol 200: 1247-1254.

Stevenson R.D. 1985. Body size and limits to the daily range of body temperature in terrestrial ectotherms. Am Nat 125: 102-117.

Svensson C.J., E. Johansson, and P. Aberg. 2006. Competing species in a changing climate: effects of recruitment disturbances on two interacting barnacle species. J Anim Ecol 75: 765-776.

Terblanche J.S., B.J. Sinclair, C.J. Klok, M.L. McFarlane, and S.L. Chown. 2005. The effects of acclimation on thermal tolerance, desiccation resistance and metabolic rate in Chirodica chalcoptera (Coleoptera: Chrysomelidae). J Insect Physiol 51:1013-1023.

Tran J.K., T. Ylioja, R.F. Billings, J. Regniere, and M.P. Ayres. 2007. Impact of minimum winter temperatures on the population dynamics of Dendroctonus frontalis. Ecol Appl 17: 882-899.

Trexler J.C. and J. Travis. 1993. Nontraditional regression analyses. Ecology 74:1629-1637.

Umina P.A., A.A. Hoffmann, A.R. Weeks, and S.W. McKechnie. 2006. An independent non-linear latitudinal cline for the snglycerol-3-phosphate (alpha-Gpdh) polymorphism of Drosophila melanogaster from eastern Australia. Genet Res 87: $13-21$.

Ward P.I., P. Jann, and W.U. Blanckenhorn. 2004. Temperaturemediated seasonal variation in phosphoglucomutase allozyme frequency in the yellow dung fly, Scathophaga stercoraria. Mol Ecol 13:3213-3218.

Watt W.B. 1992. Eggs, enzymes, and evolution: natural genetic variants change insect fecundity. Proc Natl Acad Sci USA 89: 10608-10612.

Watt W.B., P.A. Carter, and S.M. Blower. 1985. Adaptation at specific loci. IV. Differential mating success among glycolytic 
allozyme genotypes of Colias butterflies. Genetics 109:157175.

Whitham T.G., J.K. Bailey, J.A. Schweitzer, S.M. Shuster, R.K. Bangert, C.J. LeRoy, E.V. Lonsdorf, et al. 2006. A framework for community and ecosystem genetics: from genes to ecosystems. Nat Rev Genet 7:510-523.
Willmer P., G. Stone, and I. Johnston. 2004. Environmental physiology of animals. Blackwell Science, Oxford.

Zamer W.E. and R.J. Hoffmann. 1989. Allozymes of glucose6-phosphate isomerase differentially modulate pentose-shunt metabolism in the sea anemone Metridium senile. Proc Natl Acad Sci USA 86:2237-2741. 